\title{
The Assignment Method Toward Improvement Results of Dribbling Learning in Football
}

\author{
Rudi \\ Universitas Majalengka \\ alvarizi.rudi@gmail.com
}

\author{
Muhamad Abdul Fitri \\ Universitas Majalengka \\ Muh.abdulfitri@yahoo.com
}

\begin{abstract}
The purpose of this study is to determine the effect of applying the assignment method to improve dribbling learning outcomes in football games. This research used experimental method with a quantitative descriptive approach. The subjects in this study were Tara Depok Vocational high school students in Cirebon District with a population of 22 male students in class XI. This study using a total sampling technique to determine the sample to be used in the study, amounting to 22 male students. From the results of statistical calculations using the SPSS version 21 program, the Kolmogorov-Smirnov Test One-Sample test obtained significance values of 0.016 greater than 0.05 , meaning that the data in this study were normally distributed. And hypothesis testing using the Paired Samples Test with a significance level of $5 \%$ obtained results 0,000 less than 0.005. Based on these results, it can be concluded that there is a significant effect on the application of the assignment method to the improvement of dribbling learning outcomes in football games.
\end{abstract}

Keywords: assignment method, dribbling learning football

\section{INTRODUCTION}

Football is a sport that has many fans in the community. Football is known and favored by all walks of life in the world. This sport is fairly easy to play which can also be a means of entertainment. According to Pena Sehati [1] explains "Football is one of the most popular sports in the world. This sport is played by two opposing groups, each of which consists of eleven players, and because of that, the group is often called the eleven ".

Football has some basic techniques in it such as kicking the ball, stopping the ball, dribbling, passing the ball, and heading the ball. However, in this study researchers only limited the basic techniques and variations of dribbling, both using the inside legs, outside legs, and instep. According to Mielke [2] explains "dribbling is a basic skill in football because all players must be able to control the ball while moving, standing, or preparing to pass or shoot".

In the process of learning physical education teachers are expected to teach a variety of basic movement skills, techniques and strategies for games and sports, internalization of values (sportsmanship, honesty, cooperation, etc.) as well as habituation of healthy lifestyles. According to [3] explains, "Physical education is an educational process that utilizes physical activities that are planned systematically aimed at developing and enhancing individuals organically, neuromuscularly, perceptually, cognitively, and emotionally, within the framework of national education".

Based on several observations made by researchers, physical education learning dribbling material in SMK Tara
Depok Cirebon District is less effective. That is only using the demonstration method, where the teacher exemplifies the basic techniques of dribbling and then students are instructed to follow the movements that have been exemplified by the teacher without the variation of the scheme in the learning phase. So that it causes students to feel bored while learning and students only learn during the class hours, in limited time and opportunities.

Seeing these problems the researchers intend to provide a solution that is by applying the assignment method, so students have the opportunity or the intensity of learning more. 'The assignment method is a way of presenting learning materials where the teacher gives a specific task so that students do learning activities, then they must be accounted for at the next meeting' Sagala [2]. This method is suitable given because it feels too much learning material with time and facilities that are less balanced.

Based on the explanation above, if you see problems that occur in the learning process at SMK Tara Depok namely the imbalance of time, facilities and teaching materials available so that in learning students lack the opportunity to explore the material and result in a lack of student learning outcomes in dribbling material in the game soccer. So what is needed is how to increase the intensity of students in exploring teaching material. The method that can be applied in accordance with the problem that occurs is the assignment method, specifically by encouraging students to use free time for learning activities. When compared with other methods the assignment method can be more easily applied to a variety of learning materials both direct and indirect learning.

In this study, the form of assignments to be given to students is the task of movement skills and variations of football dribbling using the inside legs, outside legs, and instep, which are practiced by students in the form of video tutorials with a minimum duration of 2 minutes. Assignments will be done after class time and done in groups of 3 or 4 people who can be done anywhere as long as the assignment can be done, then at the next meeting, the task will be discussed at school.

With the assignment method, it is hoped that students learn freely but are responsible and experienced in knowing various difficulties and can overcome them because with this task students have the opportunity to compare with the results of other students.

\section{METHOD}

This research is experimental research with a quantitative approach. In this study, the design that researchers used One group pre-test - post-test design. In this design, one subject group was used. The population in this study were all male 
Based on the Table II, the significance value of 0.016 is students of class XI SMK Tara Depok, Cirebon Regency with a total of 22 students. In determining the research sample, namely determining the overall sample of a number of its population. Based on the population above, the sample of this study is 22 male students. The measuring instrument used is a skills test, which is to determine the level of students' dribbling skills. After getting the scores from the pre-test and post-test, then the data will be processed to find out whether there is an influence on the treatment of students. In this study, the data analysis technique used is the SPSS version 21 program.

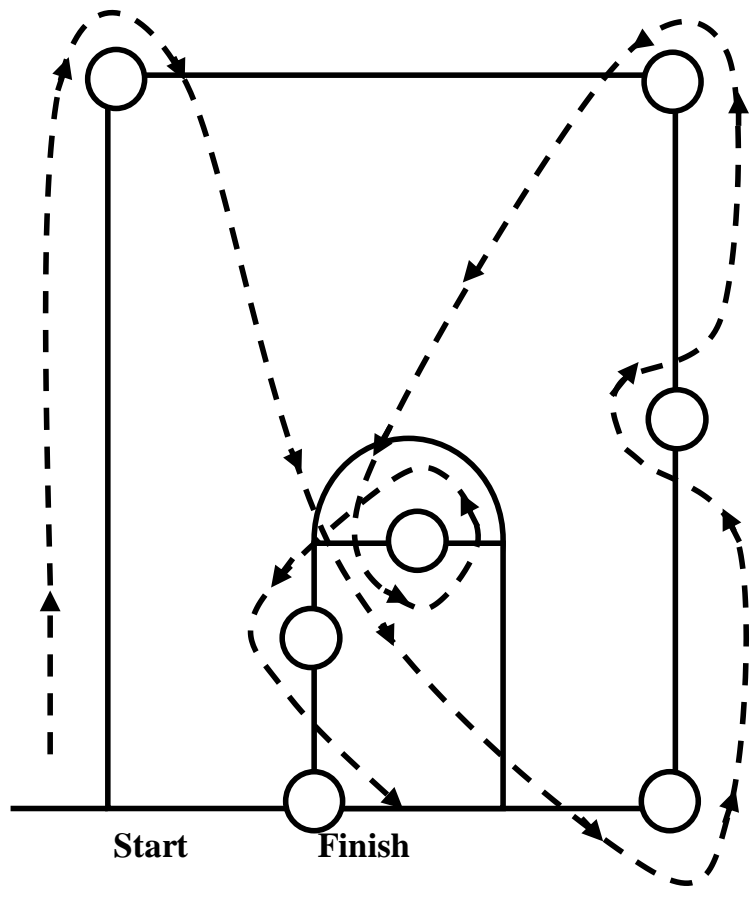

Fig. 1. Field test dribbling in football (Source: Lacy [4])

\section{RESUlTS AND DISCUSSION}

\section{A. Research Result}

TABLE I. DRIBBLING VALUE RESULTS

\begin{tabular}{|c|r|r|c|}
\hline & Pre-test & Post-test & differentd \\
\hline amount & 1.280 & 1.720 & 440 \\
\hline Mean & 58,18 & 78,18 & 20 \\
\hline $\begin{array}{c}\text { Standard } \\
\text { Deviation }\end{array}$ & 19,43 & 12,20 & 12,34 \\
\hline
\end{tabular}

Based on the Table 1 above, it can be seen an increase in dribbling learning outcomes in soccer where the pre-test results got an average of 58.18 and an increase in the post-test got an average of 78.18 meaning there was an increase in the average value of 20 .

TABLE II. NORMALITY TEST (ONE-SAMPLE KOLMOGOROV-SMIRNOV TEST)

\begin{tabular}{|l|l|l|l|}
\hline Significance & $\begin{array}{l}\text { Significance } \\
\text { level }\end{array}$ & \\
\hline 0,016 & $>$ & 0,05 & $\begin{array}{l}\text { Normally } \\
\text { distributed data }\end{array}$ \\
\hline
\end{tabular}
greater than 0.05 . So it can be concluded that the data tested were normally distributed.

TABLE III. HYPOTHESIS-TESTING (PAIRED SAMPLE TEST)

\begin{tabular}{|l|l|l|l|}
\hline $\mathrm{T}_{\text {account }}$ & & $\mathrm{T}_{\text {table }}$ & \\
\hline 7,599 & $>$ & 2,08 & Significant \\
\hline
\end{tabular}

Based on the table III, the value of $t_{\text {(count) }} 7,599 \geq t_{\text {(table) }} 2.08$ this means, that there is a significant influence of the treatment of learning by applying the method of assignment to the learning outcomes of dribbling in football games.

\section{B. Discussion}

It is known that the results of students' dribbling skills through pre-test and post-test obtained an average value of 58,18 and an increase in the post-test got an average value of 78,18 meaning there was an increase in the average value of 20. Then the data was processed with the help of the SPSS version 21 program.

Based on the normality test through the KolmogorovSmirnov Test One-Sample test, it is known that the resulting significance value of 0.016 is greater than 0.05 . So it can be concluded that the data tested were normally distributed.

The calculation of the correlation index number shows that between variable $\mathrm{X}$ (learning outcomes) and variable $\mathrm{Y}$ (assignment method) there is a significant positive correlation. With the results of $r_{x y}$ or $r$ observation of 0.789 is greater than $r_{t}$ or $r$ table that is 0.432 . It means that there is a significant positive correlation between variable $\mathrm{X}$ and variable $\mathrm{Y}$ and the hypothesis "there is a significant effect of the application of the assignment method to improve dribbling learning outcomes in football games" is acceptable.

Then the hypothesis test is done using paired samples test, with the result of sig. (2-tailed) $0,000<0.05$ means that the hypothesis is accepted. Proven by looking at the results of the pre-test mean value of 58.18 and an increase in the post-test average value of 78.18. The magnitude of the increase in the average value achieved is equal to 20 after being treated.

Based on the results of data analysis, it can be concluded that there is a significant effect of the treatment of the application of the assignment method to the learning outcomes of dribbling in football games for students of Tara Subdistrict, Depok, Cirebon, 2018.

This is consistent with the opinion of Hamdayama [5] "Assignment techniques are usually used so that students have more stable learning outcomes because students do exercises while doing assignments so that students' experiences in learning something can be more integrated". In addition to the enhancement of the motor aspect, there are also increased learning outcomes of cognitive and affective aspects. Marked with the result of the explanation in pre-Test obtained the average value of 54, 3 and in post-Test 71, 6 there is an increase of 17, 3. Pre-Test stance assessment of 58, 5 and in post-Test 77, 9 there is an increase of 19, 4 .

Based on the results of the above values, the cognitive aspect of the liquid aspect is capable of supporting a student's dribbling technique. According to [6], 
especially in the application of the assignment method, the

"If the analytical skills can develop to a person, then he will be able to apply it to a new situation creatively". That means the better the child's analysis of a movement by both himself and the other person he saw, the better the movement he will do after he analyzes the movement. Therefore, the cognitive aspect assessment in physical education should be observed.

\section{CONCLUSION}

Based on the results of processing research data that has been obtained, there is a significant increase. Sig value (2tailed) $0,000<0.05$ and the results of t-count 7.599> t-table 2.08 , it can be concluded that there is a significant influence of the application of the assignment method to the learning outcomes of dribbling in football games by students of SMK Tara Depok, Cirebon.

From the results of the research and discussion that have been stated previously, the following suggestions are as follows: (1) The application of this assignment method is used as a reference for teaching teachers to improve the quality of learning in schools, especially in learning football dribbling material. (2) To get better learning outcomes, assignment method in physical education learning should be adapted to the abilities and conditions of the students, so students can easily absorb the learning material.

\section{REFERENCES}

[1] N. Nuryanto, Pengaruh penggunaan Sasaran Bervariasi Terhadap peningkatan Hasil Belajar Teknik Dasar Passing dalam Permainan Sepakbola Pada Siswa Putra Kelas VII MTS Al-Ghozali Jatibarang, Majalengka, 2014.

[2] P. S. Kustrapsila and S. C. Y. Hartati, Pengaruh Metode Penugasan Dalam Pembelajaran Pendidikan Jasmani Terhadap Hasil Belajar Dribbling Sepakbola, Surabaya: Pendidikan Olahraga dan Kesehatan, 2013.

[3] Husdarta, Model Pembelajaran Langsung Dalam Pendidikan Jasmani dan Kesehatan, Bandung: Alfabeta, 2012.

[4] Komarudin, Penilaian Hasil Belajar Pendidikan Jasmani Dan Olahraga, Bandung: Remaja Rosdakarya, 2016.

[5] J. Hamdayama, Model dan Metode Pembelajaran Kreatif dan Berkarakter, Bogor: Ghalia Indonesia, 2015.

[6] N. Sudjana, Penilaian Hasil Proses Belajar Mengajar, Bandung: Remaja Rosdakarya, 2017. 